\title{
Direct, Indirect and Conditional Indirect Effects of Communication and Career Anxiety on Perceived Stress during Interviews in University Students - A PLS SEM Model
}

Irum ALvi

Rajasthan Technical University, Kota, Rajasthan. ORCID id: oooo-ooo1-9509-6225. Email:ialvi@rtu.ac.in

\begin{abstract}
By exploring the connections between communication and career anxiety and perceived stress, the current study contributes to a more nuanced appreciation of the university students' emotional and psychological frame of mind during interviews. The study evaluates the direct, indirect and conditional indirect effect of CA on perceived stress PS during interviews. The study also presents a complex research model, based on Preacher, Rucker, and Hayes (2007) model where the independent variable CA has a moderating effect on FCA, which is the mediator. The model is validated using empirical data, sample size 177 with 124 males (70.1\%), and 53 (29.9\%) females, with PLS-SEM using Smart PLS 3 (3.2.9). To test the hypotheses formulated, two tests were conducted using the same sample; the first one verified the direct and mediating hypotheses, the next verified the moderated mediation hypothesis. The results indicate CA affects PS. Secondly FCA mediates the effect of CA on PS. Moreover, the study confirms the effect of moderation as CA moderates the effect of FCA on PS, such that the relationship between FCA and PS is weaker when CA is small compared to when it's high, however at very higher level the effect is seen to dampen and weaker. The implications are discussed.
\end{abstract}

Keywords: emotional and psychological experiences, moderated mediation, PLS SEM, anxiety and stress.

\section{Introduction}

The global outbreak of COVID-19 is intensely changing the lives of all, including university students across the globe. In many parts of the world, as well as in India, everyone has been impacted adversely by the pandemic, especially the students. Many of them are ill-prepared for the challenges, and ill-supported by the local infrastructure and resources. Furthermore, there is concern that the pandemic may exacerbate the impact of inequitable access to jobs which is causing more anxiety among the university students. Therefore, this study based on recent empirical data aims to look into the emotional and psychological experiences of the university students, and to document their anxieties when confronted with future career anxiety exacerbated by their own lack of communication skills during the pandemic, and to assess their experiences, by exploring the direct, indirect and conditional indirect effect of communication anxiety in university students, in India.

\footnotetext{
(c) AesthetixMS 2021. This Open Access article is published under a Creative Commons Attribution Non-Commercial 4.0 International License (http://creativecommons.org/licenses/by-nc/4.o/), which permits non-commercial re-use, distribution, and reproduction in any medium, provided the original work is properly cited. For citation use the DOI. For commercial re-use, please contact editor@rupkatha.com.
} 
Researchers have focused on anxiety among university students due to its pervasiveness (Bitsko et al., 2018), which has become a cause for concern (Reetz et al. 2014). Anxiety stems from diverse causes such as new learning methodologies or responsibilities (England et al., 2017; Misra and McKean 200o). Equally significant is the role played by being judged (Cooper et al., 2018), or cold calling (Broeckelman-Post et al., 2016). The anxiety affects the university students' motivation, performance, and persistence (Bledsoe and Baskin, 2014; Eddy et al., 2015a,b; Broeckelman-Post et al., 2016; Cooper and Brownell, 2016; Cooper et al., 2018), though its levels may differ based on genders (Eddy and Brownell, 2016), ethnicities (Eddy and Hogan, 2014), or courses (Ackerman et al., 2013) etc. The present study concentrates on two types of anxiety, Communication and Future Career anxiety in university students, given the reports of anxiety and stress. The students were asked what type emotions they experienced, when they experienced them, etc. As such, the research responds to a mounting unease in comprehending how the students perform in interviews and how anxiety impacts their performances/ motivation/ persistence (Bledsoe \& Baskin, 2014; Eddy et al., 2015a,b; Broeckelman-Post et al., 2016; Cooper \& Brownell, 2016; Cooper et al., 2018), especially during interviews which are used as popular tools for selecting by organizations (McCarthy \& Cheng, 2014).

\section{Theoretical Framework}

\section{Future Career Anxiety}

The occurrence of coronavirus illnesses (COVID-19) has significantly influenced life and living of individuals globally, adversely influencing the job market, an issue that is particularly relevant to developing countries like India. This uncertainty about the future career has resulted in anxiety (Mostert \& Botha, 2013) predominantly in the undergraduates who have to confront a jobless market. As per the theory of career expansion, these undergraduates aged 23 - 25 years happen to be at the verge of forming career anticipations and commitment (Super, 1980; Tsai et al., 2017), which are being challenged as the world's economy weakens. In the present uncertain times, the students fail to make productive choices pertaining to the future (Hornak \& Gillingham, 1980; Kaplan \& Brown, 1987).

For measuring future career anxiety, FCA, the present study adopts an abridged modified measurement scale validated and developed by researchers (Tsai et al. 2017; Mahmud 2020). The scale is used as a mediating construct in the study.

\section{Communication Anxiety}

Communication and Career anxiety are negative emotions that university students feel when they are concerned about their failure (value) and uncertain about their capability to control the outcome (Pekrun et al., 2007), worsened by their lack of good communication skills. Although, both may be assignment as negative emotions, they may also be considered activating emotions in terms of their influence on students' interests and motivations. Therefore, the outcome of CA and FCA may vary from students to student based on his interest and motivation level (Pekrun et al., 2007). Both CA and FCA are situational type of anxieties which occurs when the university students dread they will present/communicate poorly in interviews for example answer questions incorrectly in front of the interviewer and get a cold-call response (Rocca, 2010; Karim and Shah, 2012), which is known to be quite widespread in university students (Bowers, 1986). Founded on control-value concept (Pekrun, 2006; Pekrun et al., 2007) pertaining to achievement emotion the university students evaluate their value and achievements, and perceive the control they have over their accomplishment, as antecedents to the anxiety they feel during the interviews. These negative 
feelings may be experienced by the students prospectively (before the interview or its outcome), or retrospectively (after the interview or its outcome) or during the interview. They may impact student accomplishment through their interaction and influence on cognition and metacognition (Zeidner and Matthews, 2005; Grossberg, 2009; Bledsoe and Baskin, 2014), inspiration (Kim and Pekrun, 2014), and commitment (Pekrun and Linnenbrink-_Garcia, 2012). For the present study, CA was measured using 12 items based on prior studies.

\section{Perceived Stress during Interviews}

The interviews being high-stake evaluative circumstances of a social kind (McCarthy \& Goffin, 2004), gives rise to stress among students during interviews (Heimberg et al., 1986; Powell et al., 2018). Like anxiety differs from individual to individual, perceived stress during the interviews also differs in students. Anxiety and stress has been found to be higher in junior students as compared to the senior ones (Bayram and Bilgel, 2008).

Given the increasing prevalence of anxiety and stress among undergraduates (Castillo and Schwartz, 2013) and use of interventions which increase or decrease anxiety in students (Broeckelman-Post et al., 2016; Cooper et al., 2018), it is important to investigate any potential links between anxiety and stress perceived by student during interviews. The current study aims to scrutinize the university students' CA and FCA anxiety and interview stress during the pandemic, a time when future career options are limited and the future looks bleak. For this purpose, Perceived Stress during interview was measured using two items based on prior studies.

\section{Research Gap and Research Objective}

Research has investigated the various causes for perceived stress and anxiety in the university students. However, the relation between Communication anxiety, future career anxiety and perceived stress during interviews has not been thoroughly studied. By exploring the connections between communication and career anxiety and perceived stress, the current study may contribute to a more nuanced appreciation of the university students' emotional and psychological frame of mind during interviews. As such it aims to fill the research gap. The present study's main objective's to find the direct, indirect or conditional indirect effects of Communication Anxiety (CA) on Perceived Stress during the Interviews (PS), as well as the effect of Future Career Anxiety (FCA), in university undergraduates in India.

\section{Research Questions}

This research asks two research questions:

1. Do the university students experience Communication Anxiety, Future Career Anxiety and perceive Stress during interviews?

2. Does Communication Anxiety affect Perceived Stress experienced by the university students during interviews directly?

3. Does Communication Anxiety affect Perceived Stress experienced by the university students during interviews indirectly?

To find potential solutions the research questions, two types of anxiety were probed: Communication Anxiety, and Future Career Anxiety. Recognizing the types of anxiety which impacts the students' performance during interviews is vital for thoughtful comprehension of the students' experiences and discovering interventions for enhancing the students' accomplishments. 
This is an essential attempt since the interview perceived stress is an acute construct in extant literature which needs more in-depth studies, and has not been theoretically and empirically studied in India. Moreover, an appreciation of the factors contributing towards interview stress may provide potential insight into how to overcome stress and anxiety.

\section{Research Framework and Hypotheses}

The study presents the research model, in which CA, CFA, and PS constructs are shown with their hypothesized relationships. This is based on Preacher, Rucker, and Hayes (2007) model where the independent variable CA itself has a moderating effect on the mediator FCA, which is mediating on the dependent variable PS, as shown in Fig 1.

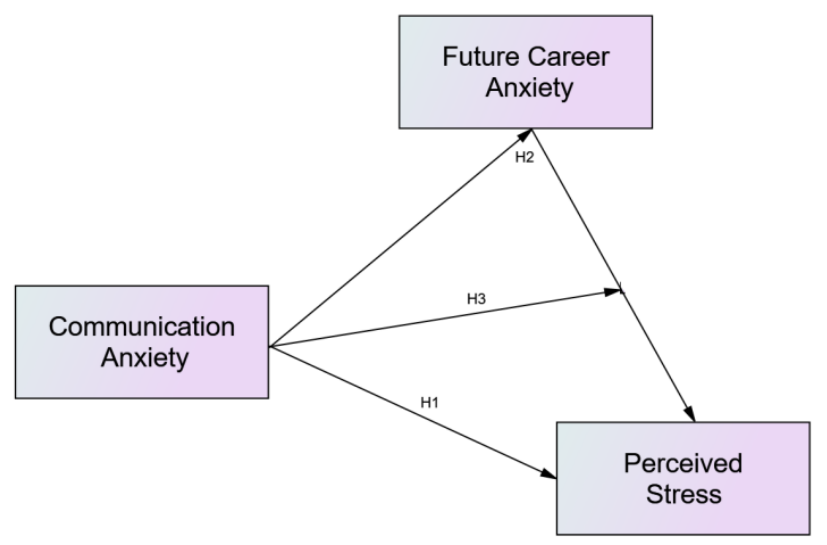

Figure 1: Research Model

Fig 1 shows the Research Model of the moderated mediation process where the independent variable (CA) moderates its own indirect effect on the dependent construct (PS) through mediator (FCA) by moderating the effect of FCA on PS, based on which the following hypotheses were framed:

Hypothesis $1\left(\mathrm{H}_{1}\right)$ : There exists an affirmative significant relationship between CA and PS.

Hypothesis $2(\mathrm{~Hz})$ : The relation between CA and PS is mediated by FCA.

Hypothesis $3\left(\mathrm{H}_{3}\right)$ : CA moderates the effect of FCA on PS, such that the relationship between FCA and PS is weaker when CA is small as compared to when it is high.

\section{Research Methodology}

\section{Research Design}

The investigation uses a quantitative method for collecting the raw data, as the aim is to discover the causal relationship amongst the select factors; such a deductive methodology was chosen as it assists the collection of quantitative information about research questions framed for the investigation. An online survey form was used to gather evidence from language learners to scrutinize their anxiety for future career and interview during the pandemic, in the month of November, 2020. SPSS and Smart-PLS 3 were utilized for data analysis. To test the hypotheses formulated, two tests were conducted using the same samples; the first one verified the direct and indirect/mediating hypotheses, then the next verified the mediating and moderating hypothesis. 


\section{Sample Characteristics}

The sample comprises 177 respondents with 124 males (70.1\%), and $53(29.9 \%)$ females. The age ranged 16 and 24 years of age, with an average age of 18.441, with Std. deviation=1.159. The study was conducted during the Pandemic period, when there was a lockdown and institutes were closed. The undergraduates were compelled to study from their respective homes and the future looked bleak and fraught with anxiety.

The mean score of CA for the full sample was 24.8249, Standard deviation=7.55343; the mean score for FCA was 5.3051, Standard deviation=3.12570, and mean score of PS was 4.1356, Standard deviation=2.34126. To determine if there was any gender-based difference between the scores of male and females in the sample for the three variables under study, $t$ test with female coded as $o$ and male coded as 1 was conducted; the t-test revealed that there was no gender-based difference between the male and female in the sample collected. The mean score of CA for male was 25.1613, Standard deviation=7.48265 and for female mean was 24.0377, Standard deviation=7.73096; the mean score for FCA male was 5.3790, Standard deviation $=3.21731$ and for female it was 5.1321, Standard deviation2.92231; the mean score of PS for male was 4.2097, Standard deviation=2.43375, while for female it was 3.9623, Standard deviation $=\mathbf{2 . 1 2 0 9 8}$. The gender-based differences were not statistically significant ( $\mathrm{p}>0.05$ ), indicating that both genders felt the same level of CA, FCA and PS.

\section{Common Method Variance}

Since the information was collected using a self-reporting strategy in a particular timeframe, evaluating the degree to which the CMV may present threat to the legitimacy of the present study's significant (Podsakoff and Organ, 1986; Tehseen et al., 2017). Harman's one-factorial analytical examination was done for analyzing CMV. It showed that all estimation indicators exposed to factor analysis by using Principal Component extraction technique with a single fixed factor without any rotations (Podsakoff et al., 2003) represented less than 50\% of variance, it indicated that CMV isn't present. The main factor showed 33.273 percent of the variance, demonstrating that the CMV difference doesn't represent a threat to the validity.

\section{Data Analysis}

The data collected were investigated by utilizing partial least square for structural equation model (PLS-SEM) using latest version of Smart PLS 3 (3.2.9). It is an algorithm-based method which, from the initial step, assesses the measurement model with internal consistency (CR), Convergence (indicator loadings and AVE), plus Discriminant Validity. Subsequent step includes assessing the underlying model which necessitates testing collinearity between the variables, evaluating the pertinence of relations for testing the hypotheses framed. The reasons of selecting PLS are: this investigation aims to explain the variances in the DV (Dependent Variable) instead of confirming

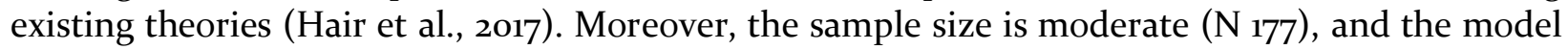
is complex, as it includes both moderation and mediation effects (Green et al., 2016). Furthermore, PLS-SEM was used as latent variable values were to be analyzed for finding influential extrapolative relevance (Hwang et al. 2020). 


\section{Results}

\section{Assessment of Measurement Model Convergent Validity (CV)}

In the model, all constructs were reflective and first-order. Table 1 shows indicator loadings of individual items, Cronbach's alpha, Dillion-Goldstein's rho, composite reliability (CR), and average variance extracted (AVE) for the constructs, which demonstrate that the data possesses validity and reliability. Hair et al. (2017) recommend 0.70 as the verge for loadings for the indicators. Therefore, three items with low loadings were deleted to enhance AVE and achive 0.50 minimum criterion (Hair et al. 2010). The Cronbach's alpha and CR display interior consistency of the instrument. Cronbach's alpha is not as much favored as CR while using SEM, and is utilized as a moderate measure for reliability and consistency (Hair et al., 2016). For the present study, CR ranging from 0.60 to 0.70 is considered acceptable as it is an exploratory investigation (Hair et al., 2017). The $C R$ values were found to be lower than 0.95 that is considered as undesirable (Hair et al., 2016). As CR is deliberated as copious, and Dillion-Goldstein's rho ( $\rho A)$ considered as the precise degree of construct reliability (Dijkstra and Henseler 2015), it was also computed.

\section{Table 1}

Results of Measurement Model

\begin{tabular}{|c|c|c|c|c|c|c|c|}
\hline $\begin{array}{l}\text { Construct } \\
\mathrm{s}\end{array}$ & $\begin{array}{l}\text { Indicator } \\
\mathrm{s}\end{array}$ & $\begin{array}{l}\text { Loading } \\
\mathrm{s}\end{array}$ & $\begin{array}{l}\text { Cronbach' } \\
\text { s } \\
\text { Alpha }\end{array}$ & $\begin{array}{l}\text { rho_ } \\
\text { A }\end{array}$ & $\begin{array}{l}\text { Composit } \\
\text { e } \\
\text { Reliability }\end{array}$ & $\begin{array}{l}\text { Average } \\
\text { Variance } \\
\text { Extracted (AVE) }\end{array}$ & Results \\
\hline \multirow{4}{*}{ FCA } & FCA 1 & 0.757 & & & & & \multirow{12}{*}{$\begin{array}{l}\text { Reliabl } \\
\text { e } \\
\text { Reliabl } \\
\text { e }\end{array}$} \\
\hline & FCA2 & 0.774 & & & & & \\
\hline & $\mathrm{FCA}_{3}$ & 0.931 & 0.863 & 0.874 & 0.863 & 0.680 & \\
\hline & PS1 & 0.727 & & & & & \\
\hline \multirow[t]{9}{*}{ PS } & $\mathrm{PS}_{2}$ & 0.861 & 0.770 & 0.786 & 0.776 & 0.635 & \\
\hline & CA1o & 0.648 & & & & & \\
\hline & CA11 & 0.669 & & & & & \\
\hline & $\mathrm{CA}_{2}$ & 0.689 & & & & & \\
\hline & $\mathrm{CA}_{3}$ & 0.808 & & & & & \\
\hline & $\mathrm{CA}_{4}$ & 0.694 & & & & & \\
\hline & $\mathrm{CA}_{5}$ & 0.661 & & & & & \\
\hline & CA6 & 0.678 & & & & & \\
\hline & CA8 & 0.661 & & & & & Reliabl \\
\hline CA & CA9 & 0.650 & 0.890 & 0.891 & 0.888 & 0.470 & \\
\hline & Moderato & & & & & & Reliabl \\
\hline $\mathrm{LA}^{*} \mathrm{FCA}$ & $r$ & & 1 & 0.778 & 1 & 1 & e \\
\hline
\end{tabular}

Table 1 also shows there is a difference in the values of alpha and CR for Interview Anxiety, but it isn't unusual because Coefficient alpha may be lesser than CR as it undervalues consistency (Peterson and Kim, 2013; Raykov, 2001). 


\section{Discriminant Validity (DV)}

Apart from the convergent validity, the discriminant legitimacy was tested for evaluating that the measures do not correlate (Ringle et al. 2010). Customarily, it was assessed using two methodologies, cross-loadings as well as Fornell and Larker's (1981) techniques were used. For the first, the indicator's outer loadings for the related construct have to be more prominent than the entirety of its loadings for all the others (Hair et al., 2016). The indicators' external loadings on the related constructs were more noteworthy than their loadings for different constructs, thereby establishing DV as shown in Table 2. Secondly, Fornell and Larcker (1981) criteria were used and the square root of the construct's AVE was contrasted with the connections with every other construct. As per norm the AVE should be more than 0.5, however AVE for CA was somewhat beneath the suggested value; nevertheless, the CR was reliable. Table 3 shows that the square-roots of AVE (appearing on the diagonal) for the variable is more noteworthy than relationships between the construct in correlation matrix (Felipe et al., 2016), demonstrating the DV is established. Estimations on diagonal (Bold) show to square-roots of AVE and off-diagonals show correlation between constructs as indicated in Table 2:

Table 2

Cross Loadings and Fornell Larcker Criteria

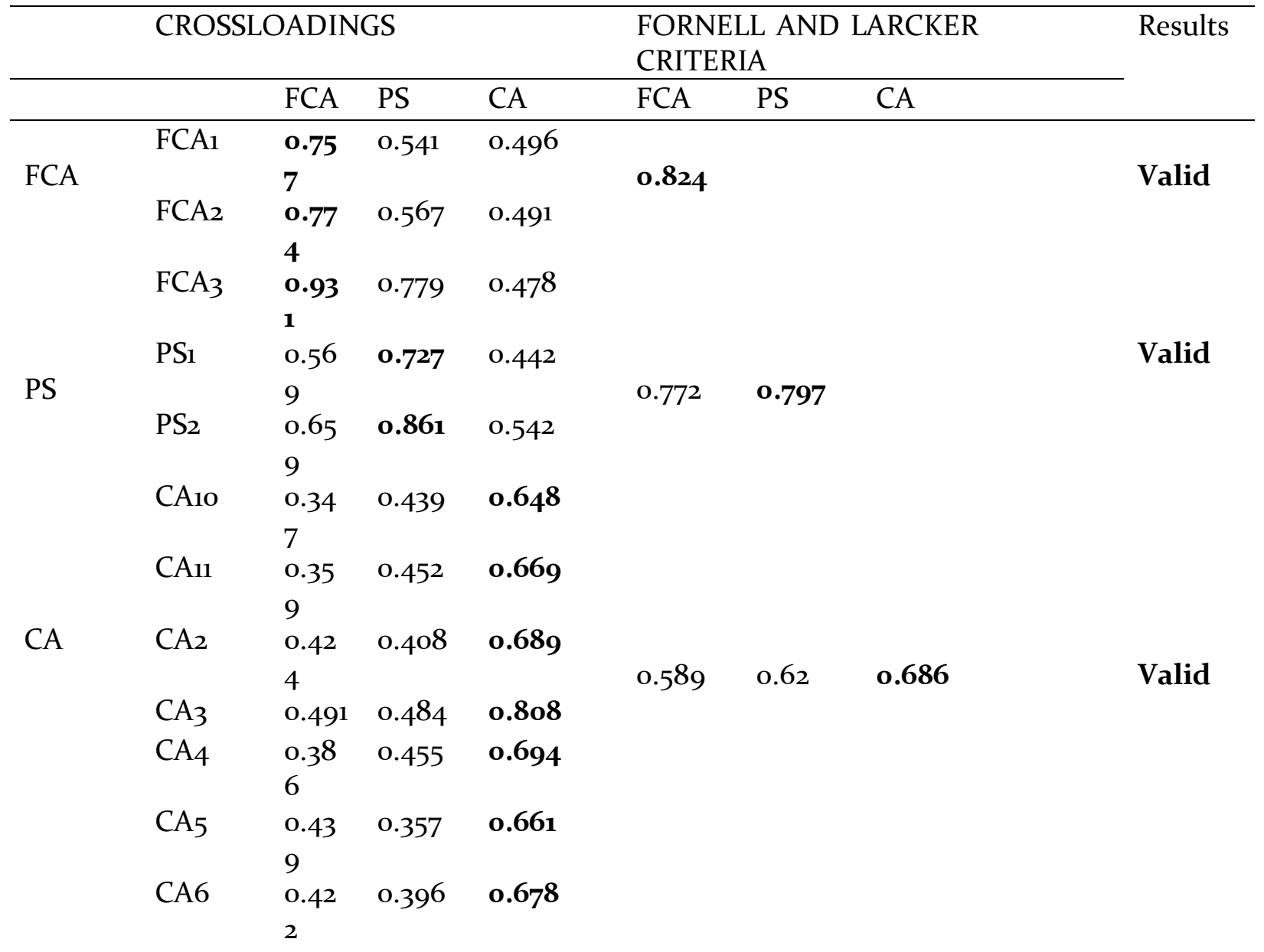




$\begin{array}{llll}\text { CA8 } & 0.37 & 0.425 & \mathbf{0 . 6 6 1} \\ & 4 & & \\ \text { CA9 } & 0.38 & 0.406 & \mathbf{0 . 6 5 0}\end{array}$

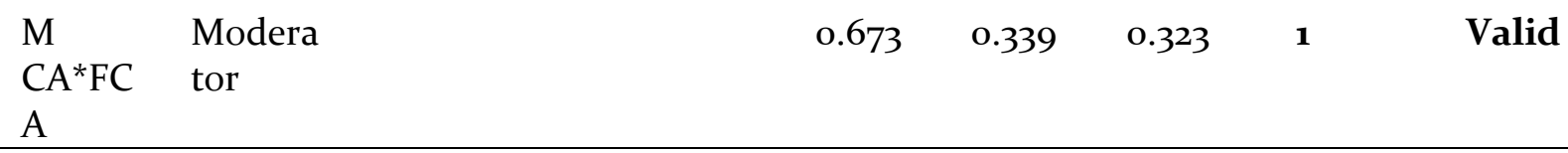

Subsequently, DV was measured using Heterotrait-Monotrait (HTMT) ratio (Hair et al., 2019), which demonstrated that HTMT values for each construct was lower than the prescribed limit 0.85 (Henseler et al., 2015). The HTMT estimations between variables were distinct and different from each other, thereby establishing discriminant validity among them as indicated in Table 3.

\section{Table 3}

Heterotrait-Monotrait (HTMT) Ratio for Constructs

\begin{tabular}{lllll}
\hline & FCA & PS & CA & Moderating Effect 1 \\
\hline FCA & & & & -- \\
PS & 0.767 & & -- \\
CA & 0.589 & 0.618 & & --- \\
Moderating Effect 1 & 0.639 & 0.316 & 0.298 & --- \\
\hline
\end{tabular}

\section{Assessment of the Structural Model}

Next, PLS-SEM inner model outcomes were measured, for which testing if the collinearity issues existed, before structural relations between constructs were assessed (Hair et al., 2016). Moreover, the model's in-sample predictive accurateness in addition to its out-of-sample predictive influence was proven (Shmueli et al. 2019). Variance Inflation factor (VIF) is utilized for distinguishing collinearity. VIF estimations above 3.33 (Diamantopoulos and Sigouw 2006) or between 3-5 show collinearity exists (Mason and Perreault Jr, 1991). Table 4 displays all the estimations for the present model met the standards, indicating that it was free from collinearity issues.

\section{Table 4}

Outer and Inner VIF

\begin{tabular}{llllll}
\hline OUTER VIF & \multicolumn{2}{l}{ INNER VIF } & FCA & PS & CA \\
\hline & VIF & & --- & 2.542 & -- \\
PS1 & 1.646 & FCA & --- & & --- \\
PS2 & 1.646 & PS & 1 & 1.554 & --- \\
FCA1 & 2.606 & LA & 1 & 1.854 & -- \\
FCA2 & 2.135 & Moderating Effect 1 & --- & & \\
FCA3 & 2.111 & & & & \\
CA10 & 3.126 & & & & \\
CA11 & 2.862 & & & &
\end{tabular}




\begin{tabular}{ll}
$\mathrm{CA} 2$ & $\mathbf{1 . 5 4 2}$ \\
$\mathrm{CA} 3$ & $\mathbf{1 . 7 9 4}$ \\
$\mathrm{CA} 4$ & $\mathbf{1 . 9 7 4}$ \\
$\mathrm{CA} 5$ & $\mathbf{2 . 0 0 4}$ \\
CA6 & 1.665 \\
$\mathrm{CA} 8$ & 1.795 \\
CA9 & $\mathbf{2 . 0 7 6}$ \\
M CA*FCA & 1 \\
\hline
\end{tabular}

Path analysis was conducted for validating the hypotheses formulated. Structural model was assessed using a non-parametric bootstrap test using a 5,00o re-sample for creating the $\beta$ and $t$ values. Next, as recommended by Hair et al. (2017), the Coefficient of Determination (R2), and Effect sizes (F2) and in-sample predictive accurateness (Dolce et al. 2017) were checked. $\mathrm{R}^{2}$ value of 0.347 and 0.686 were achieved for FCA and PS, respectively. 68.6\% variance of PS was jointly explained by CA and FCA. The $\mathrm{R}^{2}$ estimate of 0.2 is considered appropriate in behavioral sciences research (Rasoolimanesh et al. 2017). Moreover, $\mathrm{R}^{2}$ of FCA too signifies considerable predictive accurateness. The effect size (f2) was measured. F2 value of $0.35,0.15$, and 0.02 reveals effect size that is large, medium, and small respectively (Cohen 1988), thereby illustrating the size effects, which cannot be estimated using the p-values. In explaining FCA and PS, CA indicated an effect size of 0.531 and o.1. In producing $\mathrm{F}^{2}$ of PS, CFA presented a large effect, o.893. Lastly, the model predictive relevance of the endogenous construct was assessed by means of Stone-Geisser's Q2 (Geisser 1974; Stone 1974). Blindfolding method using distance $\mathrm{D}=7$ omission revealed the $\mathrm{Q}_{2}$ estimations for FCA (0.206), PS (o.357); Q2 above zero (Hair et al. 2014) established the predictive relevance for the two constructs (Fornell and Cha 1994). To measure good fit of the model, the standardized root mean square residual (SRMR) was calculated (Henseler et al., 2016), a SRMR value of o.o73, was obtained that was below the verge of acceptance o.08. Additionally, estimation of normed fix index (NFI) was 0.794 that was very close to the acceptable estimation 0.80 (Latan et al., 2017). 


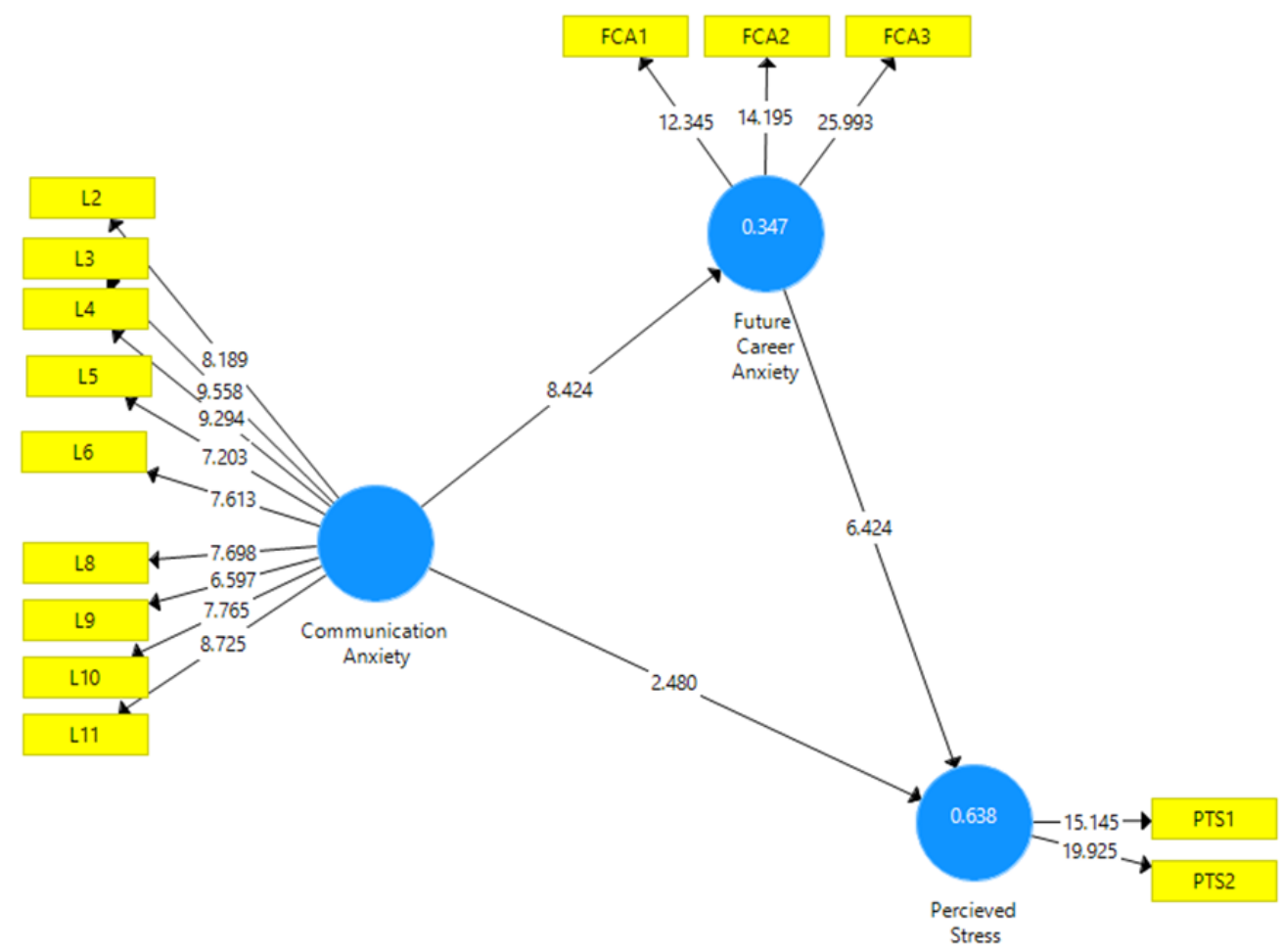

Figure 2: Direct and indirect effects of CA and FCA on PS

\section{Hypotheses Testing - Direct Effect}

As shown in Table 5, the study assessed first the direct effect of CA on PS during interviews experienced by university students. The effect of CA on PS was a significant affirmative effect ( $\beta=$ $0.253, \mathrm{t}=2.48 \mathrm{o}, \mathrm{p}=0.013, \mathrm{CI}=0.076,0.413)$, supporting H1. Moreover, FCA was found to have a critical positive effect on PS, indicating that mediation can be tested.

\section{Table 5}

Test 1 Direct and Indirect Effect

\begin{tabular}{|c|c|c|c|c|c|c|c|c|}
\hline $\mathrm{H}$ & Effects & $\begin{array}{l}\text { Std. } \\
\text { Beta }\end{array}$ & $\begin{array}{l}\text { Std } \\
\text { D }\end{array}$ & $\begin{array}{l}\mathrm{t} \\
\text { Valu } \\
\text { es }\end{array}$ & $\begin{array}{l}\mathrm{p} \\
\text { Valu } \\
\text { es }\end{array}$ & LLCI & $\begin{array}{l}\text { ULC } \\
\text { I }\end{array}$ & Results \\
\hline DIRECT & $\begin{array}{l}\text { Communication_- } \\
\text { Anxiety -> Perceived_ } \\
\text { Stress } \\
\text { Communication__ }\end{array}$ & $\begin{array}{l}0.25 \\
3\end{array}$ & 0.102 & $\begin{array}{l}2.48 \\
0\end{array}$ & 0.013 & $\begin{array}{l}0.07 \\
6\end{array}$ & 0.413 & $\begin{array}{l}\text { Accepte } \\
\text { d }\end{array}$ \\
\hline INDIRECT & $\begin{array}{l}\text { Anxiety } \quad->\quad \text { Future } \\
\text {-Career Anxiety -> } \\
\text { Perceived_Stress } \\
\text { Communication_- }\end{array}$ & $\begin{array}{l}0.36 \\
7\end{array}$ & $\begin{array}{l}0.07 \\
2\end{array}$ & 5.073 & $\begin{array}{l}0.00 \\
0\end{array}$ & $\begin{array}{l}0.26 \\
0\end{array}$ & $\begin{array}{l}0.50 \\
0\end{array}$ & $\begin{array}{l}\text { Accepte } \\
\text { d }\end{array}$ \\
\hline TOTAL & $\begin{array}{l}\text { Anxiety -> Perceived_ } \\
\text { Stress }\end{array}$ & $\begin{array}{l}0.62 \\
0\end{array}$ & $\begin{array}{l}0.07 \\
3\end{array}$ & $\begin{array}{l}8.46 \\
6\end{array}$ & $\begin{array}{l}0.00 \\
0\end{array}$ & $\begin{array}{l}0.47 \\
7\end{array}$ & $\begin{array}{l}0.72 \\
3\end{array}$ & $\begin{array}{l}\text { Accepte } \\
\text { d }\end{array}$ \\
\hline
\end{tabular}




\begin{tabular}{llll} 
& & & 0.63 \\
$\mathrm{R} 2$ & & Perceived_Stress & 8 \\
$\mathrm{Q}^{2}$ & $\left({ }^{-1}\right.$ & & 0.35 \\
SSE/SSO $)$ & & Perceived_Stress & 7 \\
& & & 0.07 \\
SRMR & & Saturated Model & 3 \\
\hline
\end{tabular}

\section{Hypotheses Testing -Indirect Effect}

Table 5 displays the result of the inner model of PLS-SEM exploration. Muller et al. (2005) proposed a construct may be regarded as a mediator if it satisfies the following conditions: The principal condition is that without a potential mediator the relation among IV and DV should be significant. Next, the predictor (CA) should significantly affect the mediator (FCA). Controlling for impact of predictor (CA), the mediator (FCA) should considerably impact DV (PS). Table 7 demonstrates that the mediation exists as all conditions are fulfilled. Moreover, the indirect effect by the mediator construct (CA to PS) was substantial. The result of bootstrapping using SmartPIS shows the indirect effect (Table 7), which are significant $(\beta=0.367, t=5.073, p<.01)$. Finally, it was observed that a change in significant path coefficient was observed in the presence of the mediation, the estimation of path coefficient increased from 0.253 to 0.367 . Notwithstanding, the substantial effect between CA and PS ( $\mathrm{t}$-value $=\mathbf{2 . 4 8 0}$ ) stayed substantial despite the existence of the mediator ( $\mathrm{t}$-value: 5.073 ). The significance of CA->PS relation shows a significant increase in the path coefficient for this relation which proposes partial mediation exists (Baron \& Kenny, 1986; Muller et al., 2005). The total effect of Communication Anxiety $->$ Perceived Stress was $\beta=0.620, t=8.466, p=0.000, C I=0.477$, 0.723). Utilizing the product coefficients approach (Hayes and Scharkow 2013), the hypothesis $\left(\mathrm{H}_{3}\right)$ was validated. The indirect effect of CA on PS through CFA was established as significant as shown in Table 5. The bias-corrected bootstrap confidence interval at 95\% presented mediation of CFA in the relation between CA and PS. The outcomes confirmed the indirect effect was much stronger than the direct effect. Therefore, the outcomes supported the hypothesis of partial mediation.

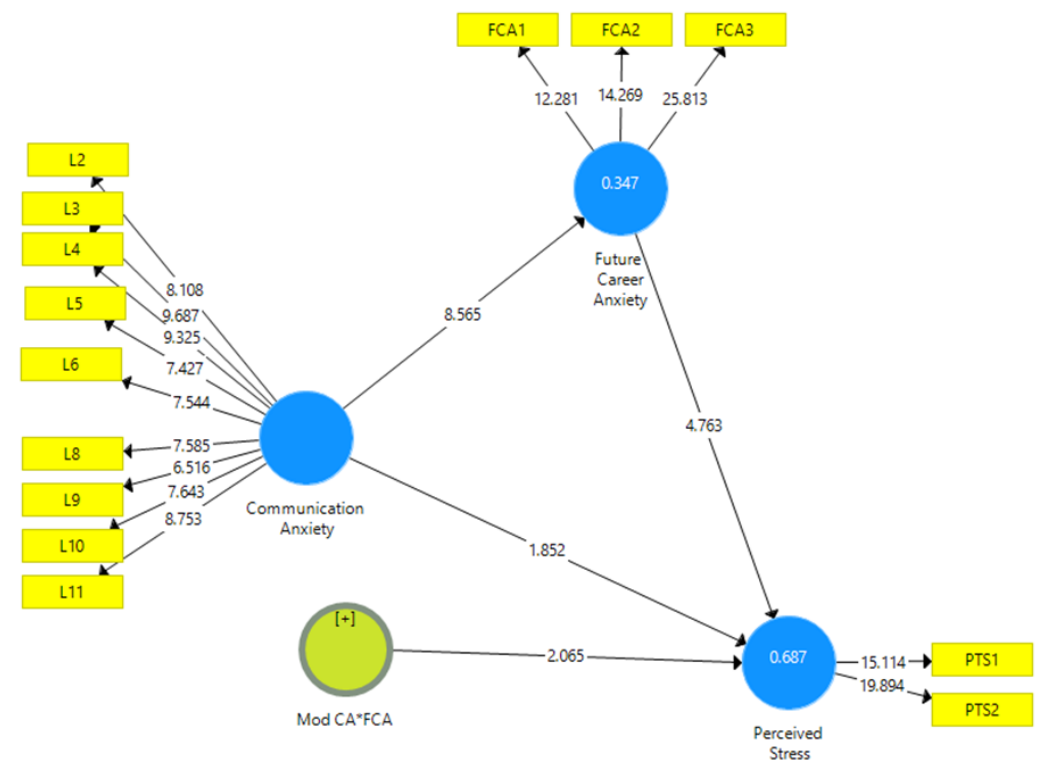

Figure 3: Direct, Indirect and Conditional Indirect Effects of CA and FCA on PS 


\section{Hypotheses Testing - Conditional Indirect Effect}

The model for indirect conditional effect was tested for finding the moderation of effect of CA on the relation between FCA and PS (Preacher 2007 model).

\section{Table 6}

Test 2 Conditional Indirect Effect

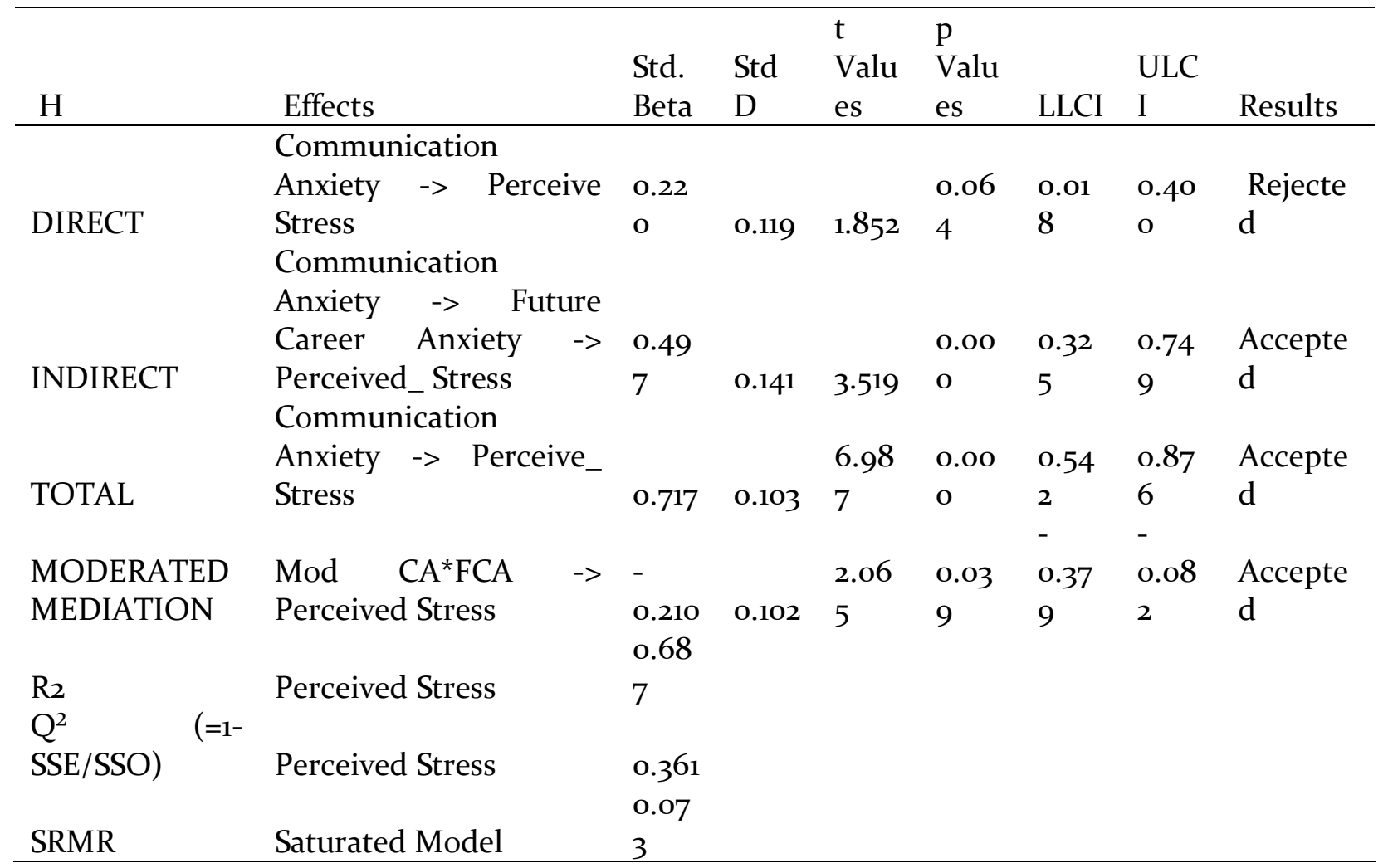

The study hypothesized that 'Hypothesis $3\left(\mathrm{H}_{3}\right)$. CA moderates the relation between FCA and PS, such that the relation is stronger when CA is high', that is CA has a moderation effect on the relationships between FCA and PS. Moderation investigation was done by using a repeated indicator approach. Table 4 displays the results for the influence of the moderator on FCA and PS relationship which indicates that CA moderates the latter. Hence the hypothesis $\mathrm{H}_{3}$ is validated (Table 5). Successively, the index of moderated mediation was evaluated to check the conditional effect (Hayes, 2015). The result $\beta=-0.210, t=2.065, \mathrm{p}=0.039, \mathrm{CI}=-0.379,-0.0820$ ) was as anticipated. The null of zero did not fall between confidence intervals, it was inferred the indirect effect is conditional on the level of CA. These outcomes validate the moderated mediation hypothesis $\left(\mathrm{H}_{3}\right)$. Therefore, CA meaningfully moderated its own indirect effect on PS. Furthermore, the direct effect of CA on PS (i.e. moderation mediation model) did not result in substantial result $(\beta=0.220, t=1.852$, $\mathrm{p}=0.064, \mathrm{CI}=0.018,0.400$ ). Hence, the results support the hypothesis of total mediation. 


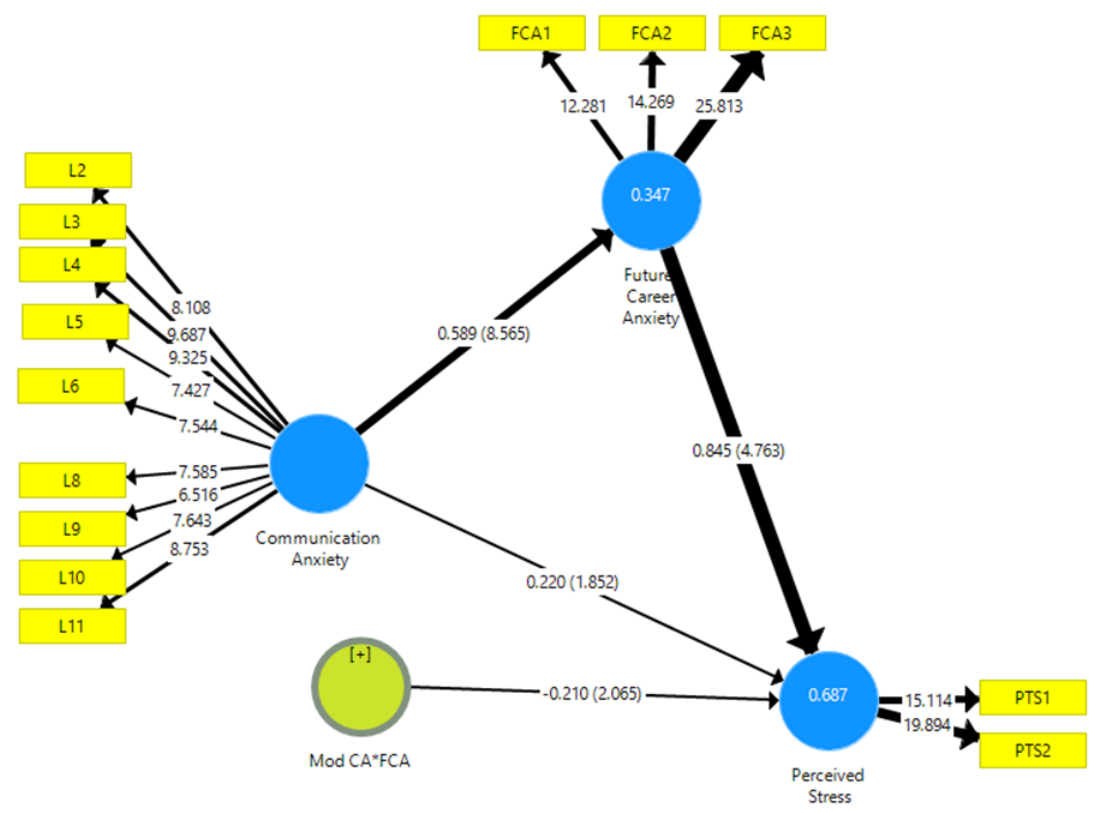

Figure 4: Direct and Indirect and conditional Indirect Effects of CA and FCA on PS (Relative)

Fig 4 shows the relative path and $t$ values for the moderated mediation model that shows that indirect effect of CA on PS is more robust than its direct effect:

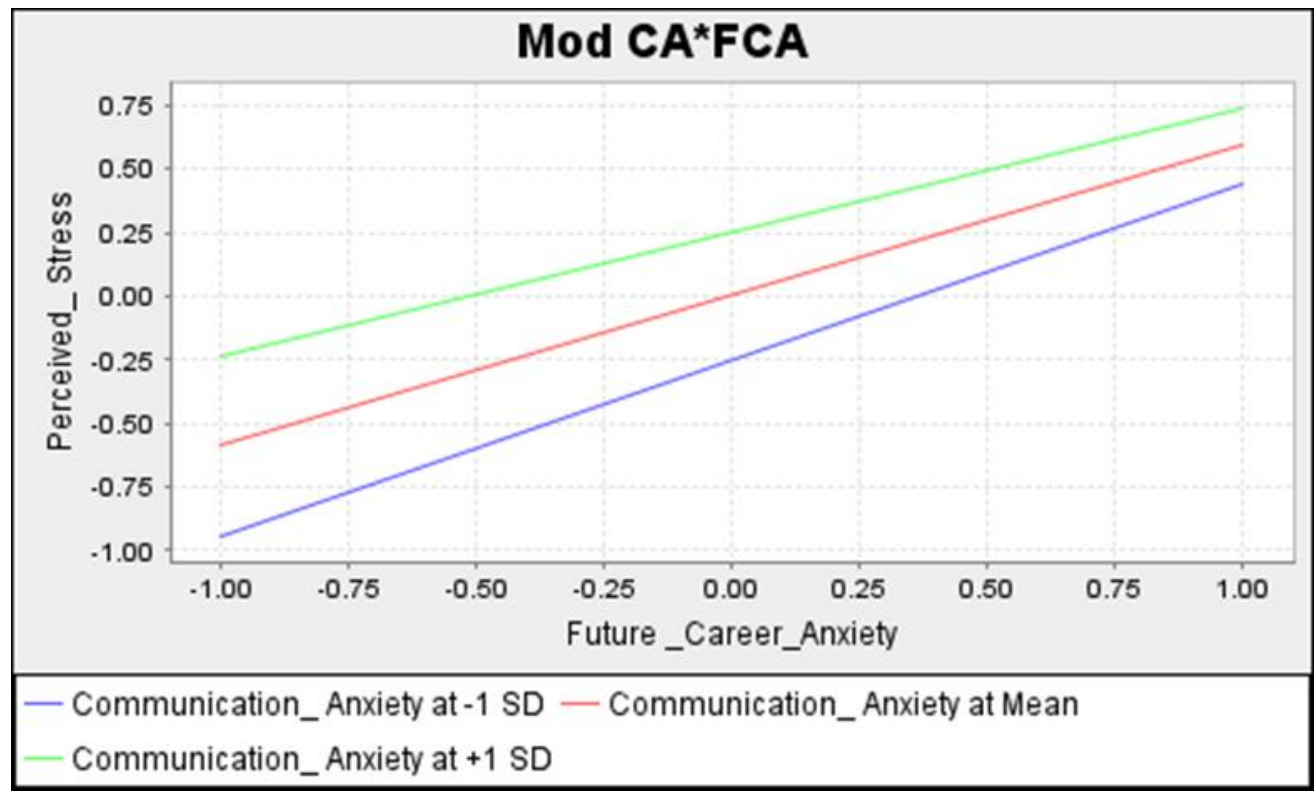

Figure 5: Moderation- Slope Showing Conditional Indirect Effect on PS

The slope shows the effect of moderation CA and FCA on the dependent variable Perceived Stress among the university students during interview (Fig 5), which displays CA moderates the effect of FCA on PS, such that the relationship between FCA and PS is weaker when CA is small compared to when it's high, however at very higher level the effect is seen to dampen and weaker as seen by the converging lines: 


\section{Discussion}

This study examined the potential links between communication anxiety and/or performance in interview and the perceived stress experienced by the university students during the pandemic, a time that is fraught with uncertainty about future as well as future career. It is perhaps not surprising that communication and future career anxiety were found to significantly affect students' performance in interviews. While perceived stress is not tantamount with anxiety, it is a direct precursor of anxiety. Therefore, when the university students expect poorly performance due to communication anxiety during the interviews, their professional objective may be thwarted altogether, resulting in a phenomenon known as performance avoidance (Elliot and Harackiewicz, 1996). This may result in decreased motivation and accomplishment (Elliot and Church, 1997; Richardson et al., 2012), leading to the students experiencing hopelessness (Pekrun and Stephens, 2010). Moreover, there is a scarcity of research works concerning the causes for higher anxiety in some students as compared to others. The present research establishes two more reasons for the stress experienced by the students during interviews, which adds to prior research which found other negative experiences to cause stress including negative stereotypes, poor educational counseling, and belief in the myth that only a few can succeed (Mallow and Greenburg, 1982; Mallow, 2006). The twin constructs investigated also contribute in aggravating the students' anxieties. The finding of the current study indicates students' anxiety is driven by future career prospects or rather the lack. Communication anxiety is known to exist in classrooms (BroeckelmanPost et al., 2016; Cooper et al., 2018) and to vary by demographics, yet not impact student success. However, the present study differs as it indicates the effect of communication anxiety on interview anxiety which may dampen the students' success. It affirms studies which have revealed lower student performance in communication is connected to elevated anxiety levels (Akgun and Ciarrochi, 2010), especially during interviews; however, students with moderate level of anxiety have been found to be better (Keeley et al., 2008), which may be explained using Yerkes-Dodson law, that illustrates a bell-shaped curved relation between anxiety and performance, with extremely low and extremely high anxiety hampering performance, but moderate anxiety improving performance (Yerkes and Dodson, 1908).

Grounded on control-value concept of achievement emotion (Pekrun, 2006; Pekrun et al., 2007) it may be assumed that the emotion felt by the students during the interviews are the expressions of their assessment of their value and the control they feel during the interview. The control-value theory proposes these considerations and responses may be controlled (Pekrun, 2006; Boekaerts and Pekrun, 2015). They may be taught to adjust their assessments of value and control thereby coping with the emotional reactions (Pekrun, 2006; Carter, 2010). Stress is negatively associated with persistence (Barthelemey et al., 2015); therefore, the students feeling stress had the same physiological reactions as anxiety, but the source of the response was measured more identifiable (Endler and Parker, 1990). Moreover, the study reveals stress and anxiety are very closely related. It may help in developing strategies that can be tested to help the students cope with stress experienced during the interviews, increasing their active coping for better adjustment and performance (Shields, 2001), increasing self-efficacy and motivation to build resilience (Dweck, 1986; Bandura,1989). These might help students present themselves in a manner which helps in self-verification (Moore, Lee, Kim, \& Cable, 2017), or be preferred/appreciated by interviewers (Kristof-Brown, 2000), or viewed as affable/sincere and competent (Amaral, Powell, \& Ho, 2019;) and honest (Jansen et al., 2012).

The present study has significant pedagogical implications in varied contexts. Nevertheless, there are some limitations also. The results are based on a sample of students from one university 
in India; thus, the results cannot be generalized to other universities. As the students decided to respond to the survey or not, the sample may be biased toward those students who are more likely to share their anxiety experiences. Moreover, the study is based on the perceived experiences of the students and does not have information on performance of the students who appeared in interviews or the outcome of the interviews.

\section{Conclusion}

The study sought to evaluate the university students' Communication Anxiety, Future Career Anxiety and perceive Stress during interviews. The study of the mediation and moderatedmediation analyzing CA among the university undergraduates seems appropriate and essential within context of COVID-19 epidemic. The results complement the extant literature by illuminating the mechanism that aggravates the students' anxiety. The findings provide an understanding of the causes for anxiety. The consequences specify that applying interventions to overcome anxiety in the context of future career uncertainty during the pandemics may be the need of the hour.

\section{Citations and References}

Ackerman, P. L., Kanfer, R., \& Calderwood, C. (2013). High school advanced placement and student performance in college: STEM majors, non-STEM majors, and gender differences. Teachers College Record, 115(10), 1-43.

Akgun, S., \& Ciarrochi, J. (2010). Learned resourcefulness moderates the relationship between academic stress and academic performance. Educational Psychology, 23(3), 287-294. https://doi.org/10.108o/ 0144341032000060129

Amaral, A. A., Powell, D. M., \& Ho, J. L. (2019). Why does IM positively influence interview ratings? The mediating role of competence and warmth. International Journal of Selection and Assessment, 27, 315327.

Bandura, A. (1989). Human agency in social cognitive theory. American Psychologist, 44(9), 1175-1184. https://doi.org/10.1037/0003-066X.44 •9.1175

Baron, R. M., \& Kenny, D. A. (1986). The moderator-mediator variable distinction in social psychological research: Conceptual, strategic, and statistical considerations. Journal of Personality and Social Psychology, 51, 1173-1182. https://doi.org/10.1037/0022-3514.51.6.1173

Barthelemey, R. S., Hedberg, G., Greenberg, A., \& McKay, T. (2015). The climate experiences of students in introductory biology. Journal of Microbiology \& Biology Education, 16(2), 138-147. https://doi.org/10 $.1128 /$ jmbe.v16i2.921

Bayram, N., \& Bilgel, N. (2008). The prevalence and socio-demographic correlations of depression, anxiety, and stress among a group of university students. Social Psychiatry and Psychiatric Epidemiology, 43(8), 667- 672. https://doi.org/10.1007/s00127-008-0345-x

Bitsko, R. H., Holbrook, J. R., Ghandour, R. M., Blumberg, S. J., Visser, S. N., Perou, R., \& Walkup, J. T. (2018). Epidemiology and impact of health care provider-diagnosed anxiety and depression among US children. Journal of Developmental \& Behavioral Pediatrics, 39(5), 395-403. https://doi .org/10.1097/DBP.0oooooooooooo571

Bledsoe, T. S., \& Baskin, J. J. (2014). Recognizing student fear: The elephant in the classroom. College Teaching, 62(1), 32-41. https://doi.org/10 .1080/87567555.2013.831022

Boekaerts, M., \& Pekrun, R. (2015). Emotions and emotion regulation in academic settings. In Como, L., \& Anderman, E. M. (Eds.), Handbook of educational psychology (pp. 76-9o). New York: Routledge 
Bowers, J. W. (1986). Classroom communication apprehension: A survey. Communication Education, 35(4), 372-378. https://doi.org/10.108o/ 03634528609388361

Broeckelman-Post, M., Johnson, A., \& Schwebach, J. R. (2016). Calling on students using notecards: Engagement and countering communication anxiety in large lecture. Journal of College Science Teaching, 45(5), 27-32. https://doi.org/10.2505/4/jcst16_045_05_27

Carter, A. (2010). Evaluating the best of coping program: Enhancing coping skills in adolescents (Doctoral dissertation). Ontario, Canada: University of Windsor. Retrieved December 15, 2018, from http://scholar.uwindsor .ca/etd/479

Castillo, L. G., \& Schwartz, S. J. (2013). Introduction to the special issue on college student mental health. Journal of Clinical Psychology, 69(4), 291-297. https://doi.org/10.1002/jclp.21972

Cohen, J. (1988). Statistical power analysis for the behavioral sciences, Second Ed., New Jersey: Hillsdale, Lawrence Earlbaum Associates.

Cooper, K. M., \& Brownell, S. E. (2016). Coming out in class: Challenges and benefits of active learning in a biology classroom for LGBTQIA students. CBE-Life Sciences Education, 15(1), ar37. https://doi.org/10.1187/ cbe.16-01-0074

Cooper, K. M., Downing, V. R., \& Brownell, S. E. (2018). The influence of active learning practices on student anxiety in large-enrollment college science classrooms. International Journal of STEM Education, 5, 23. https://doi.org/10.1186/s40594-018-0123-6

Diamantopoulos, A., \& Siguaw, J. A. (2006). Formative versus reflective indicators in organizational measure development: A comparison and empirical illustration. British Journal of Management, 17(4), 263-282. https://doi.org/10.1111/j.1467-8551.2006.00500.x

Dijkstra, T. K., \& Henseler, J. (2015). Consistent and asymptotically normal PLS estimators for linear structural equations. Computational Statistics \& Data Analysis, 81, 10-23. https://doi.org/10.1016/j.csda.2014.07.008

Dolce, P., Esposito Vinzi, V., \& Lauro, C. (2017). Predictive path modeling through PLS and other componentbased approaches: Methodological issues and performance evaluation. In H. Latan and R. Noonan (Eds.) Partial least squares path modeling: Basic concepts, methodological issues and applications (153172). Cham: Springer International Publishing

Dweck, C. S. (1986). Motivational processes affecting learning. American Psychologist, 41(10), 1040-1048. https://doi.org/10.1037/0003-066X.41.10.1040

Eddy, S. L., \& Brownell, S. E. (2016). Beneath the numbers: A review of gender disparities in undergraduate education across science, technology, engineering, and math disciplines. Physical Review Physics Education Research, 12(2), 020106

Eddy, S. L., \& Hogan, K. (2014). Getting under the hood: How and for whom does increasing course structure work? CBE-Life Sciences Education, 13(3), 453-468. https://doi.org/10.1187/cbe.14-03-0050

Eddy, S. L., Brownell, E. S., Thummaphan, P., Lan, M., \& Wenderoth, M. P. (2015a). Caution, student experience may vary: Social identities impact a student's experience in peer discussions. CBE-Life Sciences Education, 14(4), ar45. https://doi.org/10.1187/cbe.15-05-0108

Eddy, S. L., Converse, M., \& Wenderoth, M. (2015b). PORTAAL: A classroom observation tool assessing evidence-based teaching practices for active learning in large science, technology, engineering, and mathematics classes. CBE-Life Sciences Education, 14(2), ar23. https://doi.org/ 10.1187/cbe.14-06-0095

Elliot, A. J., \& Church, M. A. (1997). A hierarchical model of approach and avoidance achievement motivation. Journal of Personality and Social Psychology, 72, 218-232. https://doi.org/10.1037/oo22-3514.72.1.218 
Elliot, A. J., \& Harackiewicz, J. M. (1996). Approach and avoidance achievement goals and intrinsic motivation: A mediational analysis. Journal of Personality and Social Psychology, 70, 461-475. https://doi.org/ 10.1037/0022-3514.70.3.461

Endler, N. S., \& Parker, J. D. A. (1990). Stress and anxiety: Conceptual and assessment issues. Stress Medicine, 6, 243-248. https://doi.org/10.1002/ smi.2460o60310

England, B. J., Brigati, J. R., \& Schussler, E. E. (2017). Student anxiety in introductory biology classrooms: Perceptions about active learning and persistence in the major. PLoS ONE, 12(8), eo182506. https://doi .org/10.1371/journal.pone.0182506

Felipe, C., Roldán, J. and Leal-Rodríguez, A.L. (2016). An explanatory and predictive model for organizational agility. Journal of Business Research, 69 (10), 4624-4631.

Fornell, C., \& Larcker, D. F. (1981). Evaluating structural equation models with unobservable variables and measurement error. Journal of Marketing Research, 18, 39-50. https://doi.org/10.2307/3151312

Fornell, C., \& Cha, J. (1994) Partial least squares. In R. P. Bagozzi (Ed.), Advanced methods in marketing research (52-78). Cambridge: Blackwell.

Geisser, S. (1974). A predictive approach to the random effect model. Biometrika, 61(1), $101-107$. https://doi.org/10.1093/biomet/61.1.101.

Green, J.P., Tonidandel, S. and Cortina, J. (2016). Getting through the gate: statistical and methodological issues raised in the reviewing process. Organizational Research Methods, 193() , 402-432.

Grossberg, S. (2009). Cortical and subcortical predictive dynamics and learning during perception, cognition, emotion, and action. Philosophical Transactions: Biological Sciences, 364, 1223-1234. https://doi .org/10.1098/rstb.2008.0307

Hair Jr, J. F., Hult, G. T. M., Ringle, C., \& Sarstedt, M. (2016). A Primer on Partial Least Squares Structural Equation Modeling (PLS-SEM). London, UK: Sage Publications.

Hair, J.F.J., Hult, G.T.M., Ringle, C.M. and Sarstedt, M. (2017), A Primer on Partial Least Squares Structural Equation Modeling (PLS-SEM), 2nd ed., Sage Publications, Thousand Oaks, CA.

Hair, J. F., Black, W. C., Babin, B. J., Anderson, R. E., \& Tatham, R. L. (2010). Multivariate data analysis (7th Ed). Upper Saddle River, NJ: Pearson/Prentice Hall.

Hair, J. F., Hult, G. T., Ringle, C. M., \& Sarstedt, M. (2014). A primer on partial least squares structural equation modeling (PLS-SEM). Thousand Oaks, Sage Publications.

Hair, J. F., Sarstedt, M., \& Ringle, C. M. (2019). Rethinking some of the rethinking of partial least squares. European Journal of Marketing, 53, 566-584. https://doi.org/10.1108/EJM-10-2018-0665

Hair, J. F., Sarstedt, M., Ringle, C. M., \& Gudergan, S. P. (2017). Advanced issues in partial least squares structural equations modeling (PLS-SEM). Thousand Oaks, Sage Publications.

Hayes, A. F. (2015). An index and test of linear moderated mediation. Multivariate Behavioral Research, 50(1), 1-22.

Hayes, A. F., \& Scharkow, M. (2013). The relative trustworthiness of inferential tests of the indirect effect in statistical mediation analysis: Does method really matter?. Psychological science, 24(10), 1918-1927.

Heimberg, R. G., Keller, K. E., \& Peca-Baker, T. A. (1986). Cognitive assessment of social-evaluative anxiety in the job interview: Job interview self-statement schedule. Journal of Counseling Psychology, 33(2), 190195 .

Henseler, J., Hubona, G. and Ray, P.A. (2016). Using PLS path modeling in new technology research: updated guidelines. Industrial Management \& Data Systems, Vol. 116 No. 1, pp. 2-20. 
Henseler, J., Ringle, C. M., \& Sarstedt, M. (2015). A new criterion for assessing discriminant validity in variancebased structural equation modeling. Journal of the Academy of Marketing Science, 43(1), 115-135. https://doi.org/10.1007/s11747-014-0403-8

Hornak J., Gillingham B. (1980). Career indecision: A self-defeating behavior. Personnel \& Guidance Journal, 59(4), 252-253. 10.1002/j.2164-4918.1980.tboo543.X

Hwang, H., Sarstedt, M., Cheah, J. H., \&Ringle, C. M. (2020). A concept analysis of methodological research on composite-based structural equation modeling: Bridging PLSPM and GSCA. Behaviormetrika, 47(1), 219241. https://doi.org/10.1007/s41237-019-00085-5

Jansen, A., König, C. J., Stadelmann, E. H., \& Kleinmann, M. (2012). Applicants self-presentational behavior: What do recruiters expect and what do they get? Journal of Personnel Psychology, 11, 77-85

Kaplan D. M., Brown D. (1987). The role of anxiety in career indecisiveness. The Career Development Quarterly, 36(2), 148-162. 10.1002/j.2161-0045.1987.tboo786.x

Karim, N. H. A., \& Shah, M. I. A, (2012). Silence is not golden: Investigating classroom participation anxiety among university students. World Applied Sciences Journal, 20(2), 228-235.

Keeley, J., Zayac, R., \& Correia, C. (2008). Curvilinear relationships between statistics anxiety and performance among undergraduate students: Evidence for optimal anxiety. Statistics Education Research Journal, 7(1), 4-15

Kim, C., \& Pekrun, R. (2014). Emotions and motivation in learning and performance. In Spector, J. M. (Ed.), Handbook of research on educational communications and technology (65-75). New York: Springer Science+Business Media.

Kristof-Brown, A. L. (200o). Perceived applicant fit: Distinguishing between recruiters perceptions of personjob and person-organization fit. Personnel Psychology, 53, 643-671.

Latan, H., Charbel Jose, C.J. and Lopes de Sousa Jabbour, A.B. (2017). Ethical awareness, ethical judgment and whistleblowing: a moderated mediation analysis. Journal of Business Ethics, 1-41.

Mahmud, M. S., Talukder, M. U., Rahman, S. M. (2020). Does 'fear of COVID-19' trigger career anxiety? An empirical investigation considering depression from COVID-19 as a mediator. Journal of Social Psychiatry, 67, 1-11. https://doi.org/10.1177.0020764020935488

Mallow, J. V. (2006). Science anxiety: Research and action. In Mintzes, J. J., \& Leonard, W. H. (Eds.), Handbook of college science teaching (3-14). Arlington, VA: NSTA Press

Mallow, J. V., \& Greenburg, S. L. (1982). Science anxiety: Causes and remedies. Journal of College Science Teaching, 11(6), 356-358. Retrieved December 15, 2018, from www.jstor.org/stable/42965923

Mason, C. H., \& Perreault Jr, W. D. (1991). Collinearity, power, and interpretation of multiple regression analysis. Journal of Marketing Research, 28(3), 268-28o. https://doi.org/10.1177\%2Foo2224379102800302

McCarthy, J., \& Goffin, R. (2004). Measuring job interview anxiety: Beyond weak knees and sweaty palms. Personnel Psychology, 57(3), 607-637.

Misra, R., \& McKean, M. (2000). College students' academic stress and its relation to their anxiety, time management, and leisure satisfaction. American Journal of Health Studies, 16(1), 41-51.

Moore, C., Lee, S. Y., Kim, K., \& Cable, D. M. (2017). The advantage of being oneself: The role of applicant selfverification in organizational hiring decisions. Journal of Applied Psychology, 102(11), 1493-1513.

Mostert K., Botha H. (2013). Significant predictors associated with the career uncertainty of university students. South African Journal of Higher Education, 27(3), 501-521.

Muller, D., Judd, C. M., \& Yzerbyt, V. Y. (2005). When moderation is mediated and mediation is moderated. Journal of Personality and Social Psychology, 89, 852-863. https://doi.org/10.1037/oo22-3514.89.6.852 
Pekrun, R. (2006). The control-value theory of achievement emotions: Assumptions, corollaries, and implications for educational research and practice. Educational Psychology Review, 18(4), 315-341. https://doi .org/10.1007/s10648-0o6-9029-9

Pekrun, R. P., \& Stephens, E. J. (2010). Achievement emotions in higher education. In Smart, J. C. (Ed.), Higher education: Handbook of theory and research (257-306). New York: Springer.

Pekrun, R., \& Linnenbrink-Garcia, L. (2012). Academic emotions and student engagement. In Christenson, S. L. (Ed.), Handbook of research on student engagement (259-282). New York: Springer Science+Business Media.

Pekrun, R., Frenzel, A. C., Goetz, T., \& Perry, R. P. (2007). The control-value theory of achievement emotions: An integrative approach to emotions in education. In Schutz, P., \& Pekrun, R. (Eds.), Emotion in education (13-36). Amsterdam: Academic

Peterson, R. A., \& Kim, Y. (2013). On the relationship between coefficient alpha and composite reliability, Journal of Applied Psychology, 98, 194-198. https://doi.org/10.1037/aoo30767

Podsakoff, P.M., MacKenzie, S.B., Lee, J.Y. and Podsakoff, N.P. (2003), "Common method biases in behavioral research: a critical review of the literature and recommended remedies", Journal of Applied Psychology, 88 (5), 879-903.

Podsakoff, P. M., MacKenzie, S. B., Lee, J. Y., \& Podsakoff, N. P. (2003). Common method biases in behavioral research: a critical review of the literature and recommended remedies. Journal of Applied Psychology, 88(5), 879-903.

Powell, D. M., Stanley, D. J., \& Brown, K. N. (2018). Meta-analysis of the relation between interview anxiety and interview performance. Canadian Journal of Behavioural Science/Revue canadienne des sciences du comportement, 50, 195-207.

Preacher, K. J., Rucker, D. D., \& Hayes, A. F. (2007) Addressing moderated mediation hypotheses: Theory, Methods, and Prescriptions. Multivariate Behavioral Research, 42, 185-227.

Rasoolimanesh, S. M., Jaafar, M., Kock, N., \& Ahmad, A. G. (2017). The effects of community factors on residents' perceptions toward World Heritage Site insc iption and sustainable tourism development. Journal of Sustainable $\quad$ Tourism, 25(2), 198-216. https://doi.org/10.1080/09669582.2016.1195836

Raykov, T. (1998). Coefficient alpha and composite reliability with interrelated non homogeneous items. Applied Psychological Measurement, 22(4), 375-385. https://doi.org/10.1177\%2Fo14662169802200407.

Reetz, D.R., Krylowicz, B., Mistler, B. (2014). The association for university and college counseling center directors annual survey. Aurora, 51, 60506.

Richardson, M., Abraham, C., \& Bond, R. (2012). Psychological correlates of university students' academic performance: A systematic review and meta-analysis. Psychological Bulletin, 138(2), 353-387. https://doi .org/10.1037/aoo26838

Ringle, C. M., Sarstedt, M., \& Mooi, E. A. (2010). Response-based segmentation using finite mixture partial least squares. In R. Stahlbock, S. F. Crone, \& S. Lessmann (Eds.) Data Mining, Annals of Information Systems 8 (pp. 19-49). Boston, MA: Springer US. https://doi.org/10.1007/978-1-4419-1280-0_2

Rocca, K. A. (2010). Student participation in the college classroom: An extended multidisciplinary literature review. Communication Education, 59(2), 185-213. https://doi.org/10.108o/03634520903505936

Shields, N. (2001). Stress, active coping, and academic performance among persisting and nonpersisting college students. Journal of Applied Biobehavioral Research, 6(2), 65-81. https://doi.org/10.1111/j.1751 9861.2001.tboo107.X 
Shmueli, G., Sarstedt, M., Hair, J. F., Cheah, J. H., Ting, H., Vaithilingam, S., \& Ringle, C. M. (2019). Predictive model assessment in PLS-SEM: Guidelines for using PLSpredict. European Journal of Marketing, 53(11), 2322-2347. https://doi.org/10.1108/EJM-02-2019-0189

Stone, M. (1974). Cross-validatory choice and assessment of statistical predictions. Journal of the Royal Statistical Society. Series B (Methodological), 36(2), 111-147. https://doi.org/10.1111/j.25176161.1974.tboog94.x

Super D. E. (1980). A life-span, life-space approach to career development. Journal of Vocational Behavior, 16(3), 282-298.

Tehseen, S., Ramayah, T. and Sajilan, S. (2017). Testing and controlling for common method variance: a review of available methods. Journal of Management Sciences, 1(2), 142-168.

Tsai C.-T., Hsu H., Hsu Y.-C. (2017). Tourism and hospitality college students' career anxiety: Scale development and validation. Journal of Hospitality \& Tourism Education, 29(4), 158-165.

Yerkes, R. M., \& Dodson, J. D. (1908). The relationship of strength of stimulus to rapidity of habit formation. Journal of Comparative Neurology and Psychology, 18(5), 459-482. https://doi.org/10.1002/cne.920180503

Zeidner, M., \& Matthews, G. (2005). Evaluation anxiety: Current theory and research. In Elliot, A. J. \& Dweck, C. S. (Eds.), Handbook of competence and motivation (141-166). New York: Guilford. 